\title{
Correction to: Iran's Multi-ethnic Mosaic: A 23-Year Perspective
}

\author{
Mahdi Majbouri $^{1} \mathbb{D} \cdot$ Sanaz Fesharaki $^{2}$
}

Published online: 12 March 2019

(C) UNU-WIDER 2019

\section{Correction to: Soc Indic Res \\ https://doi.org/10.1007/s11205-017-1800-4}

The article Iran's Multi-ethnic Mosaic: A 23-Year Perspective, written Mahdi Majbouri and Sanaz Fesharaki, was originally published electronically on the publisher's internet portal (currently SpringerLink) on November 2017 without open access.

With the copyright holders decision to opt for Open Choice the copyright of the article changed on February 2019 to (C) UNU-WIDER 2019, and this book is licensed under the terms of the Creative Commons Attribution-NonCommercial-ShareAlike 3.0 IGO License (https://creativecommons.org/licenses/by-nc-sa/3.0/igo/), which permits any noncommercial use, sharing, adaptation, distribution, and reproduction in any medium or format, as long as you give appropriate credit to the UNU-WIDER, provide a link to the Creative Commons licence and indicate if changes were made. If you remix, transform, or build upon this book or a part thereof, you must distribute your contributions under the same licence as the original.

The original article can be found online at https://doi.org/10.1007/s11205-017-1800-4.

Mahdi Majbouri

mmajbouri@babson.edu

Sanaz Fesharaki

sanaz@vt.edu

1 Economics Division, Babson College, 231 Forest St, Wellesley, MA 02457, USA

2 Economics Department, Virginia Tech, 3016 Pamplin Hall, 880 West Campus Drive, Blacksburg, VA 24061, USA 